\title{
Covid-19. Civic Universities, Societal Innovation and the Recovery of Local Communities
}

\author{
John Goddard*
}

\begin{abstract}
Corona virus has had a differential impact on not only various age and ethnic groups but also on different localities. In many of these places, universities have hitherto acted in dual roles as key anchor and as knowledge institutions. During the crisis, many universities have worked with heath service providers, businesses, local authorities and the community and voluntary sector with real pace, skill and scale in a way that has reinforced the trust and confidence of local people in their universities. Whilst the immediate focus has been on the contribution of the medical and life sciences, civically minded universities have also drawn on the social sciences to help public authorities address the challenges of economic and social recovery in a more sustainable and inclusive way. This has required them to put citizens at the heart of placed based societal innovation. Going forward universities and their funders must learn from the good they have done during the health crises and then seek to build a 'new normal' based on values rather than on quasi-artificial performance metrics. A values approach would embed a university more strongly within local government structures where it could then benefit from political influence and financial systems. Firms of all sizes and from all places, local and national would then be much more aware of the contribution universities can make to society in the round.
\end{abstract}

Keywords: Societal Innovation; Universities; Covid-19; Recovery; European Economy; Global Markets

\section{Universities and Covid-19}

There is abundant evidence that Corona virus has had a differential impact on not only various age and ethnic groups but also on different localities, particularly those with a long history of economic and related social disadvantage. In many of these places, universities have hitherto acted in dual roles as key anchor and knowledge institutions. Their contributions to both the local economy and society have been documented in many reports, for example by the UK's Civic University Commission

\footnotetext{
* Emeritus Professor of Regional Development Studies, Newcastle University (john.goddard@ @cl.ac.uk)

Goddard, J. (2021). Covid-19. Civic Universities, Societal Innovation and the Recovery of Local Communities. Symphonya. Emerging Issues in Management (symphonya.unicusano.it), (1), 56-63. https://dx.doi.org/10.4468/2021.1.06goddard
} 
(UPP Foundation, 2019a), the EC's Smart Specialisation Platform's work on higher education $^{1}$ and UNESCO's Global University Network for Innovation ${ }^{2}$. These endeavours have supported networks of universities sharing knowledge about how to work with local partners in economic, for example the UK's Civic University Network $^{3}$ and the Erasmus+ CIVIS_network ${ }^{4}$.

During the crisis many universities of their own volition have worked with heath service providers, businesses, local authorities and the community and voluntary sector with real pace, skill and scale in a way that has reinforced the trust and confidence of local people in their universities.

\section{Key Challenges}

Whilst the immediate focus has been on the contribution of the medical and life sciences social scientists have been helping public authorities address the following questions ${ }^{5}$ :

- Resilience. What sectors, firms, households in our region are most at risk from various economic impacts? What is the likely scale of these impacts? What policies or investments have proven effective in other economic crises, in other times or places?

- To what extent are current government funding initiatives and risk-mitigation policies reaching their targeted organisations (what is the level of uptake) and what impact are these having in real-time?

- Contagion effects. What kinds of direct and indirect effects - e.g. between sectors and other sectors and on households - are likely to be triggered by redundancies and reduced incomes? What level of burden might this place on specific public-sector services and agencies (and where)?

- Geographical impacts - What are the spatial inequalities that are emerging - e.g. in terms of access to basic services at a micro-area level; 'food deserts'; concentrations of those unable to work at home and key workers.

- Employment support and those on the margins of the labour market - What challenges and opportunities are posed for employment support providers and beneficiaries? What are the support needs that are emerging? What are the implications for the non-employed and those at the margins of the labour market?

Going forward the task is to ensure not just that their regional/local economy bounces back from the shock but that it builds back to a better, ideally more resilient, more inclusive and more productive way of working ${ }^{6}$.

Responding sensitively and appropriately in the different phases of the crisis is important not only to maximise the contribution that universities can make but also because good civic collaboration in this time of crisis will have positive effects on the reputation of universities and longer-term place-based working.

$\square$ As the President of the Regional Studies Association has said: «It is very unlikely, when the pandemic is over that social and economic life will simply return to its pre-pandemic state - nor should it: how we organise our lives and our social and economic systems will need to be rethought. The importance of properly 
funding health and social services, of reducing social and spatial inequalities in incomes and welfare, of reorganising supply chains and productions systems to make them less geographically fragmented and less fragile, of making future economic growth both more inclusive and sustainable, these all, it is to be hoped, will become key imperatives of policy innovation. What is certainly clear is that the impacts and consequences of the current crises will vary not only between countries, but also within them, between regions, cities and localities, thereby elevating the need for policies that incorporate explicit initiatives that are sensitive and specific to individual places» (Martin, 2020).

\section{Specific Questions}

Specific questions that universities can address include:

- What growth opportunities are there likely to be for local firms during the recovery? What kinds of investments and policy interventions have been effective in other post-recession upturns and/or other countries?

- What needs to be done in the short and medium term to support the selfemployed who face particularly great uncertainty and will need to adapt to changed circumstances? Self-employment was already an issue prior to the pandemic - particularly the growth of the gig economy - but the lags in responding to the needs of those not in employment have highlighted the vulnerability of self-employed people to economic shocks that cannot be anticipated and over which they have no control.

- In what ways is the crisis changing behaviours amongst consumers and employees and promoting specific kinds of innovation and changes in business models as organisations and individuals adapt to working remotely, with supply limitations, reduced travel etc.? How does that impact differentially, by sector?

- Methodological and evaluation issues raised by the shock. e.g. What has Covid19 shown us about the strengths and weaknesses of socio-economic data and are there better ways of linking information gathering and two-way communication between business and local government and economic development agencies and universities?

\section{Working with the community}

Given the far reaching impact of the pandemic on society, university work with business needs to be matched by work with communities so that «Everyone is heard and believe in, given a fair opportunity to thrive, and the ability to influence the things that matter to them. Every community comes together, looks out for each other, respects difference and enables everyone to belong and society as a whole, values and invests in everyone and in every community». Civically minded universities can help communities to recover by sharing power, changing practices to help people thrive and just not cope and providing collaborative leadership to achieve systemic change. 
Going forward, many disadvantaged regions will face great challenges in rebuilding their local economies and civil society. Universities can play a key role in both spheres but in doing this they will have to adopt a model, which puts citizens and the heart of placed based societal innovation. Up until now, this civic role has not figured highly in the policy of national governments about the purpose of and funding for higher education. Now some universities face their own Covid-19 induced crisis with many anchor institutions in left -behind places under financial pressure. This all points to the need to re-think the role of universities in society.

\section{The Role of Government}

Some European governments already require universities to have a 'third mission' serving the public good, broadly defined to include engaging with business and the community but seldom with specific reference to city and regional development. By definition, this is inferior to the first and second missions of teaching and research. University research performance and that of individual academics has been assessed by papers published in peer reviewed journals (often linked to a single discipline) and by frequency of citation as a measure of impact on the global scientific field. Various bodies and the media to inform global rankings of universities then use these performance indicators, aggregated across different disciplines. Many governments have wanted to see Universities in their countries ranked as high possible as part of national global positioning strategies and as a means of attracting international students and leading scholars. There may be direct local impacts through the scale of the HEI as a local employer but that is an incidental outcome. In the field of education, governments measure outputs by such indicators as successful completion of degree programmes, student satisfaction surveys and post graduate employment outcomes (which again might not be local).

When it comes to the third mission, there are no ready metrics; outcomes can turn up in a variety of spheres beyond H.E. such as improved business performance through research links and employment of skilled graduates and these may have specific regional impact. Perhaps the most transparent local impact is in the form of spin out businesses established by researchers and graduates - this is why many regional authorities support business incubators. In short, it is partly for reason of accountability that third mission activity has remained an unfunded mandate in most countries.

\section{Leadership and Management of Universities}

This model of public funding and accountability has implications for how long established HEIs are led and managed (Goddard et al, 2016). These institutions are traditionally organised around academic disciplines and teaching and research are separate functions. Academic staff are rewarded and incentivised by research outputs and management is light touch making institutional steering difficult. Insofar as a third mission is recognised the focus is on income generation rather than the public good - there is in effect a hard boundary between the HEI and the outside world. The consequence is that many traditional universities are in the region but not part of the 
region. Newer institutions such as universities of applied science may differ insofar as they may place greater emphasis on teaching and community service and with stronger management. So regional authorities wishing to work with HEIs in their area need to understand the institution's origins and trajectories and their management structures - talking to the rector may have little impact in traditional universities! (European Union - Regional Policy, 2011).

\section{The Territorial Dimension to University Regulation}

The above picture of publically funded higher education is changing rapidly and Covid-19 is now a key driver. In essence governments and citizens are asking not only what HEIs are good at ( the research excellence metric) but what are they good for ( the contribution to the challenges facing civil society locally as well as globally) (Brink, 2018). The good for question has a territorial dimension not least because many political processes operate this way - mayors and members of parliaments ask: we have an HEI in our city/region but what is it doing for us in helping recovery? These questions are particularly pertinent in lagging regions - how can the HEIs contribute to raising regional competiveness and rebuilding society in a sustainable and inclusive way. Therefore, the discourse is increasingly about the responsibility of HEIs to place based development in the round - economic, social and environmental through teaching as well as research (Goddard, 2009).

\section{The Role of Research and Links to Innovation}

It is important to set this discussion in the context of the rapidly changing thinking at a European level about the links between research and innovation and which should be influencing how HEIs act locally in response to the crisis. In essence, it is being increasingly recognised that the science push or linear model of innovation based on research commercialisation that has hitherto underpinned third mission activity and the role of universities in regional development is outmoded.

$\square$ «Innovation happens in complex ecosystems. Too often, we
imagine innovation in a linear way, as a pipeline with inputs and
outputs. [...] We need more open collaboration both globally and
locally between citizens, government and inventors... Focus on
people, places and processes... our innovation economy is not a
roman aqueduct but a muddy pond. It requires all actors -
corporate, academic, civil and political» (Madelin, 2016).

This resonates with principles of Responsible Research and Innovation (Presidency of the Council of the European Union, 2014) and the UN Sustainable Development Goals. The key point here is that Covid-19 intersects with the suite of societal challenges most of which are local as well as global. Addressing them requires building capacity for collaboration by diverse actors coming together in 'quadruple helix' partnerships embracing HEIs, business, public authorities and organisations representing civil society. For universities, responding to Covid-19 is a long-term 
challenge that will require an 'open ended mission' and engagement with the socioeconomic system as a whole, inducing or requiring transformation of institutions and the regional innovation system. Universities will have to embrace multiple objectives, addressing not merely the economic but also social and environmental concerns. They will need to engage in complex, interlinked, global and local processes that require multi-level action and coalitions. More transdisciplinary research and innovation and close working between different parts of the public and private sector and enhanced public - private partnerships will be required. A key role for 'stakeholders', 'users', 'co-producers of knowledge' building human capital through education, training and lifelong learning will be essential rather than a 'nice to have'.

\section{The Civic University}

These drivers suggest that universities now need to become truly civic 'anchor institutions' bridging the global and the local. Therefore, in contrast to the traditional institution, engagement with society locally and globally has to become embedded in teaching and research with no distinction between core and periphery activities. For example, students and graduates working in the local public and private sectors to establish the social relations through which the co-production and exchange of knowledge takes place. Regional authorities and universities will need to work together through action learning projects that build local transversal leadership capacity to underpin open forms of governance. In this way, universities can help a region and its HEIs become better interconnected internally and externally and add to the stock of human capital, broadly defined, that can aid recovery.

There is an urgent need for universities from the bottom up to seize the initiative and come up with their own collective plans and policies. In the UK, the Civic University Network provides a ready-made platform do this. It is well-placed to work with a diverse group of institutions across the UK who have committed to prepare Civic University Agreements (UPP Foundation, 2019b). The Network is analysing how universities are working to identify and map needs at city and regional levels and mobilising their expertise in supporting civic partners to find solutions to the crisis. It is examining how the uneven distribution of research expertise and resources, coupled with financial pressures, might further disadvantage 'left behind places' and considering what steps could be taken by the sector and government to support the recovery process in these localities. It is developing and rolling out tools that universities, local authorities/agencies and civic partners at metropolitan/neighbourhood levels can use to link user need(s) with university capability. It is using virtual workshops to share experience, expertise and ideas that can help cities and local communities create resilient pathways to recovery and maximising the reach of the research to the whole of the UK (Goddard \& Mc Nulty, 2020).

\section{Conclusion}

There is no reason why this model could not operate a European scale building on the experience of the Smart Specialisation Platform. Evidence and experiential 
learning when linked to the vast body of social science knowledge accumulated over decades about the role of universities in city and regional development could contribute to shaping a less geographically blind national higher education systems across Europe. In the absence of a clear national and European policy steer each university will have to find new ways of responding to the impact of the crisis on the education of individuals at all levels, the local economy, health and wellbeing, aggravated inequality and the potential collapse of key sectors (e.g. culture and leisure). The outcome could be less competition and more collaboration with other HE institutions, colleges and schools and eventually to an altogether more nuanced national and European guidance for the development of whole education system.

Within this context, individual universities could learn from the good they have done during the health crises and then seek to build their own futures based on what values they think to be most important. A 'new normal' based on values rather than on quasi-artificial performance metrics may emerge. A values approach would embed a university more strongly within its local government structure where it could benefit from its political influence and financial systems. Firms of all sizes and from all places, local and national, should then be much more aware of its cultures, capacities and motivations. Demand for socially relevant research and philanthropic donations linked to demonstrable community benefits and not just the university in isolation could follow. There will be a need for new investments and it will take time for the societal benefits to feed through. However, the longer-term societal outcomes can only be better than the kinds of short term and narrow focus of the technical and financial outputs required of universities by current systems.

\section{Bibliography}

Andreosso-O'Callaghan, B. (2020). Industrial Policy Response to the Covid 19 Crisis in Ireland - A Filière Approach. Symphonya. Emerging Issues in Management (symphonya.unicusano.it), (2), 80-88. http://dx.doi.org/10.4468/2020.2.09andreosso

Bellandi, M. (2020). Some Notes on the Impacts of Covid-19 on Italian SME Productive Systems. Symphonya. Emerging Issues in Management (symphonya.unicusano.it), (2), 63-72.

http://dx.doi.org/10.4468/2020.2.07bellandi

Bianchi, P., \& Labory, S. (2020). Industrial Policy and Covid Crisis: Mobilising All Levels of Government for Smart Complementarity. Symphonya. Emerging Issues in Management (symphonya.unicusano.it), (2), 73-79.

http://dx.doi.org/10.4468/2020.2.08bianchi.labory

Bourdin S., Torre A. (2020). The Circular Economy as a Means of Territorialisation of the EU Industry. Symphonya. Emerging Issues in Management (symphonya.unicusano.it), (2), 33-40.

http://dx.doi.org/10.4468/2020.2.04bourdin.torre

Brink, C. (2018). The Soul of the University: Why Excellence is not Enough_Bristol, University Press

Brondoni, S. M. (2020). US, China, Japan, SK \& EU: Industrial Strategies and Global Firm Challenges. Symphonya. Emerging Issues in Management (symphonya.unicusano.it), (2), 89-103.

http://dx.doi.org/10.4468/2020.2.10brondoni

Cappellin, R. (2020). The New European Industrial Strategy and the Company's Organization Models. Symphonya. Emerging Issues in Management (symphonya.unicusano.it), (2), 7-24.

http://dx.doi.org/10.4468/2020.2.02cappellin

Ciciotti, E. (2020). A New Territorial-Industrial Policy after the Covid 19 Crisis. Symphonya. Emerging Issues in Management (symphonya.unicusano.it), (2), 25-32. 
http://dx.doi.org/10.4468/2020.2.03ciciotti

European Union - Regional Policy (2011). Connecting Universities to Regional Growth: A Practical Guide. Smart Specialisation Platform.

https://ec.europa.eu/regional_policy/en/information/publications/guides/2011/connectinguniversities-to-regional-growth-a-practical-guide

Goddard, J. (2009). Reinventing the Civic University. NESTA. https://www.nesta.org.uk/report/re-inventing-the-civic-university/

Goddard, J., \& Mc Nulty, D. (2020). Universities and the recovery of local communities from the COVID-19 crisis: A role for the social sciences. Campaign for Social Science.

https://campaignforsocialscience.org.uk/news/universities-and-the-recovery-of-localcommunities-from-the-covid-19-crisis-a-role-for-the-social-sciences/

Goddard, J., Hazelkoorn, E., Kempton, L., \&Vallance, P. (2016). The Civic University: The Policy and Leadership Challenges London, Elgar.

Madelin, R. (2016) Opportunity Now: Europe's Mission to Innovate. Luxembourg: Publications Office of the European Union.

Martin, R. (2020). A Message from our President. Regional Studies Association.

https://www.regionalstudies.org/news/a-message-from-our-president/

Presidency of the Council of the European Union (2014). Rome Declaration on Responsible Research and Innovation in Europe.

https://ec.europa.eu/research/swafs/pdf/rome_declaration_RRI_final_21_November.pdf

Rodríguez-Cohard, J. C., Juste-Carrión, J. J., \& Vásquez-Barquero, A. (2020). Local Development Policies: Challenges for Post-COVID-19 Recovering in Spain. Symphonya. Emerging Issues in Management (symphonya.unicusano.it), (2), 41-54.

http://dx.doi.org/10.4468/2020.2.05rodriguez.juste.vazquez

Tuffs, R., Larosse, J., \& Corpakis, D. (2020). Post-Covid-19 Recovery Policies: Place-based and Sustainable Strategies. Symphonya. Emerging Issues in Management (symphonya.unicusano.it), (2), 55-62.

http://dx.doi.org/10.4468/2020.2.06tuffs.larosse.corpakis

UPP Foundation (2019a). Truly Civic: Strengthening the connection between universities and their places. The final report of the UPP Foundation Civic University Commission.

https://upp-foundation.org/wp-content/uploads/2019/02/Civic-University-Commission-Final$\underline{\text { Report.pdf }}$

UPP Foundation (2019b). A Guide to preparing Civic University Agreements.

https://upp-foundation.org/wp-content/uploads/2019/07/2202-UPP-Foundation-A-Guide-topreparing-Civic-University-Agreements-Booklet-A4-digital.pdf

\footnotetext{
Notes

${ }^{1}$ https://s3platform.jrc.ec.europa.eu/hess

${ }^{2}$ http://www.guninetwork.org/report/higher-education-world-6

${ }^{3}$ https://www.shu.ac.uk/about-us/civic-university-network

${ }^{4}$ https://civis.eu

${ }^{5}$ https://www.birmingham.ac.uk/research/city-redi/wm-redi/economic-social-impacts-of-covid19on-the-west-midlands.aspx

${ }^{6}$ https://blog.bham.ac.uk/cityredi/meet-john-goddard-professor-of-universities-and-cities-city-rediwm-redi-university-of-birmingham/
} 